\title{
Fermentation pattern of tropical grass haylage and digestibility compared to hay in equine diet
}

\author{
Padrão de fermentação da silagem de gramínea tropical e \\ digestibilidade comparada ao feno na dieta de equinos
}

\author{
Maria Lindomárcia Leonardo da Costa $^{1 *}$; Adalgiza Souza Carneiro de Rezende ${ }^{2}$; \\ Mayara Gonçalves Fonseca ${ }^{3}$; Jéssica Lage ${ }^{4}$; Patrícia Guimarães Pimentel ${ }^{5}$; Ivone \\ Yurika Mizubuti ${ }^{6}$; Guilherme Passos de Freitas ${ }^{7}$; Guilherme Rocha Moreira ${ }^{8}$; \\ Ângela Maria Quintão Lana²; Eloísa de Oliveira Simões Saliba ${ }^{2}$
}

\begin{abstract}
Hay production is the most common form of forage conservation methods for horse feeding. However, haylage can be an alternative to hay. The present research assessed the nutritional value of Tifton- 85 haylage by fermentation pattern, bromatological composition, and apparent digestibility compared to hay in the diet of Quarter Horse mares. Haylage was prepared with $700.0 \mathrm{~g}$ of dry matter (DM) $\mathrm{kg}^{-1}$ added with a biological inoculum and was assessed at 1,3,7,14,28, and 56 days of production. At 14 days, the protein content had decreased from 192.0 to $173.2 \mathrm{~g} \mathrm{~kg}^{-1} \mathrm{DM}$. The opposite was found for ammoniacal nitrogen, which rose from 0.61 to $1.14 \mathrm{~g} \mathrm{~kg}^{-1} \mathrm{DM}$ of total nitrogen. No differences were found for the variables NDF, ADF, hemicellulose, $\mathrm{pH}$, acetic acid, propionic acid and butyric acid, whose values were 734.3, 316.5 and $416.9 \mathrm{~g} \mathrm{~kg}^{-1} \mathrm{DM}, \mathrm{pH} 5.47$ and $0.06,0.003,0.03 \mathrm{~g} \mathrm{~kg}^{-1} \mathrm{DM}$, respectively. Lactic acid contents were higher after 28 days of haylage production, reaching $2.39 \mathrm{~g} \mathrm{~kg}^{-1} \mathrm{DM}$ at the last assessment. The contents of aflatoxins, fumonisin, and zearalenone in the plant were similar to those in the haylage at $0.95 \mu \mathrm{g} \mathrm{kg}^{-1}, 0.60 \mathrm{mg} \mathrm{kg}^{-1}$, and $0.71 \mu \mathrm{g} \mathrm{kg}^{-1}$, respectively. The digestibility assay showed an increase in protein digestibility in the diet with haylage $\left(675.1 \mathrm{~g} \mathrm{~kg}^{-1} \mathrm{DM}\right)$ compared to hay $(579.1 \mathrm{~g}$ $\mathrm{kg}^{-1} \mathrm{DM}$ ) of the same grass. Haylage can potentially be used to feed horses and its use is recommended starting at 28 days of production.
\end{abstract}

Key words: Ensiled forage. Grass. Horse. Intake. Wilting.

1 Prof ${ }^{\mathrm{a}}$, Departamento de Zootecnia, Universidade Federal da Paraíba, UFPB, Areia, PB, Brasil. E-mail: lindomarcia@cca.ufpb.br

2 Profs., Escola de Veterinária, Universidade Federal de Minas Gerais, UFMG, Belo Horizonte, MG, Brasil. E-mail: adalgizavetufmg@gmail.com; lana@vet.ufmg.br; saliba@vet.ufmg.br

3 Discente, Curso de Doutorado, Programa de Pós-Graduação em Medicina Veterinária, Universidade Estadual Paulista Júlio de Mesquita Filho, UNESP, Campus Jaboticabal, SP, Brasil. E-mail: mayaragoncalvesf@hotmail.com

4 Discente, Curso de Doutorado, Programa de Pós-Graduação em Zootecnia, UFMG, Belo Horizonte, MG, Brasil. E-mail: jessicalage@gmail.com

5 Prof ${ }^{\mathrm{a}} \mathrm{Dr}^{\mathrm{a}}$, Departamento de Zootecnia, Universidade Federal do Ceará, UFCE, Ceará, CE, Brasil. E-mail: pgpimentel@hotmail.com

${ }^{6}$ Prof $^{\mathrm{a}} \mathrm{Dr}^{\mathrm{a}}$, Departamento de Zootecnia, Universidade Estadual de Londrina, UEL, Londrina, PR, Brasil. E-mail: mizubuti@uel.br

7 Discente do Curso de Graduação em Medicina, Faculdade de Ciências Médicas de Minas Gerais, FCMMG, Belo Horizonte, MG, Brasil. E-mail: guilhermepfreitas.vet@gmail.com

8 Prof., Departamento de Estatística e Informática, Universidade Federal Rural de Pernambuco, UFRPE, Recife, PE, Brasil. E-mail: guirocham@gmail.com

* Author for correspondence 


\title{
Resumo
}

\begin{abstract}
A produção de feno é a forma mais comum entre os métodos de conservação de forragem para alimentação de cavalos. Entretanto, a silagem pode ser alternativa ao uso do feno. A presente pesquisa avaliou o valor nutricional da silagem de Tifton- 85 através do padrão de fermentação, composição bromatológica e digestibilidade aparente, em comparação com feno na dieta de éguas da raça Quarto de Milha. Foram confeccionadas silagens com 700,0 g matéria seca (MS) $\mathrm{kg}^{-1}$ e aditivada com inoculante biológico, as quais foram avaliadas $1,3,7,14,28$ e 56 dias de produção. Aos 14 dias foi verificado redução na concentração proteica de 192,0 para 173,2 $\mathrm{g} \mathrm{kg}^{-1}$ MS. O inverso foi encontrado para o nitrogênio amoniacal que aumentou de 0,61 para 1,14 do nitrogênio total. Não foram verificadas diferenças para as variáveis FDN, FDA, hemicelulose, $\mathrm{pH}$, ácido acético, propiônico e butírico que apresentaram 734,3; 316,$5 ; 416,9 \mathrm{~g} \mathrm{~kg}^{-1} \mathrm{MS}, \mathrm{pH} 5,47$ e 0,$06 ; 0,003 ; 0,03 \mathrm{~g} \mathrm{~kg}^{-1} \mathrm{MS}$, respectivamente. As concentrações de ácido láctico foram superiores a partir dos 28 dias de produção, atingindo $2,39 \mathrm{~g} \mathrm{~kg}^{-1} \mathrm{MS}$ no último tempo avaliado. As concentrações de aflatoxinas, fumonisina e zearalenona foram semelhantes entre planta e silagem, que foram $0,95 \mu \mathrm{g} \mathrm{kg}^{-1} ; 0,60 \mathrm{mg} \mathrm{kg}^{-1}$ e $0,71 \mu \mathrm{g} \mathrm{kg}^{-1}$, respectivamente. No ensaio de digestibilidade, foi verificado aumento na digestibilidade da proteína na dieta com silagem $(675,1 \mathrm{~g}$ $\left.\mathrm{kg}^{-1}\right)$ quando comparada ao feno $\left(579,1 \mathrm{~g} \mathrm{~kg}^{-1}\right)$ da mesma gramínea. A silagem apresenta potencial para utilização na alimentação de equinos sendo recomendada sua utilização a partir de 28 dias de ensilada.

Palavras-chave: Cavalo. Emurchecimento. Forragem ensilada. Gramínea. Ingestão.
\end{abstract}

\section{Introduction}

Among the forage conservation methods for horse feeding, hay production is the most common. Although silages also work as a nutritional strategy for this species, they may cause digestive disorders in these animals if not properly produced and managed, particularly in tropical climates.

Ensiled forages with high dry matter content, called haylage, are well accepted by horses and are widely used in several countries, particularly in Europe, as a replacement to hay, which is one of the main causes of respiratory diseases in horses. Hay making also results in losses during production, transportation and storage (MÜLLER; UDÉN, 2007; RAGNARSSON; LINDBERG, 2008).

Haylage is defined as wilted forage with high DM contents between 50 and $75 \%$. The material is later ensiled while removing as much air as possible from the bales (BERGERO et al., 2002). According to NRC (2007) ensiled forage has higher digestibility of nutrients than hay of the same grass.

In face of the need for understanding haylage production with tropical grasses, which poses an alternative to the forage conservation methods employed in horse feeding, the present research aimed to assess the fermentation patterns and digestibility of haylage compared to hay in horse diets.

\section{Materials and Methods}

This research's protocol was submitted to the Committee of Ethics and Animal Experimentation CETEA of the Federal University of Minas Gerais, which analyzed and approved it under registration number $055 / 10$.

Two trials were carried out in a farm in the city of Itaúna, MG, Brazil. In the first, haylages were prepared to assess the fermentation pattern, while the second assessed the digestibility in horses.

The forage was harvested in an irrigated 5 ha plot fertilized with 20:15 kg NK ha-1. The plot had been previously planted with Tifton-85 (Cynodon spp.) grass, which was cut at 30 days of growth at about $28 \mathrm{~cm}$ height. A harvester cut the grass at 5 $\mathrm{cm}$ from the soil surface and the material was spread and mixed several times with rakes for homogenous drying. 
During sun drying, the dry matter contents were determined through representative sampling at several random sites in the field followed by the formation of a pooled sample for drying in a microwave oven according to the technique described by Pastorini et al. (2002). Several samples were collected during the day of harvest until 700.0 g DM kg-1 was reached with no change in weight. Immediately after the predetermined DM content was reached, the grass was formed into rows for addition of a biologic inoculant with Lactobacillus plantarum $\left(2.5 \times 10^{10} \mathrm{CFU} \mathrm{g}^{-1}\right)$ and Pediococcus pentosaceus $\left(2.5 \times 10^{10} \mathrm{CFU} \mathrm{g}^{-1}\right)$ according to the manufacturer's recommendations. The grass was then placed into high-strength $70 \times 40 \times 30 \mathrm{~cm}$ nylon and polyethylene bags and the air was removed with a vacuum sealer following the technique described by Kung Júnior et al. (2010). The haylages were gradually opened to assess the fermentation profile at $1,3,7,14,28$, and 56 days after production.

Contents of volatile fatty acids (VFAs), lactic acid, $\mathrm{pH}$, and ammonia-N were determined in aqueous extract of the haylage, obtained through the technique described by Müller (2009). The contents of DM, crude protein (CP), gross energy (GE), neutral detergent fiber (NDF), and acid detergent fiber (ADF) were determined at the Animal Nutrition Laboratory of the Veterinary School of the Federal University of Minas Gerais according to Silva and Queiroz (2002).

The Toxicology Laboratory of the same institution performed tests to check for mycotoxins and to quantify their contents using commercial kits (Veratox, Neogen Corporation, Europe) with readings in a spectrophotometer according to the ELISA method at $650 \mathrm{~nm}$. This analysis was carried out only in the plant immediately after harvest and in the haylage 56 days after production.

The study followed a completely randomized design with four replicates. The data underwent normality and homoscedasticity analyses using Lilliefors and Bartlett's tests, respectively. ScottKnott test $(\mathrm{P}<0.05)$ was employed. Only descriptive statistics was used to assess the mycotoxin contents.

Trial 2 corresponded to the consumption and digestibility assay. The treatments assessed consisted of diets comprising concentrate and forage preserved as haylage or hay of Tifton-85 (Table 1).

Table 1. Chemical composition $\left(\mathrm{g} \mathrm{kg}^{-1} \mathrm{DM}\right)$ and gross energy $\left(\mathrm{Mcal} \mathrm{kg}^{-1}\right)$ of the feeds and experimental diets.

\begin{tabular}{lccccc}
\hline \multirow{2}{*}{ Item } & \multicolumn{3}{c}{ Feed } & \multicolumn{2}{c}{ Diet } \\
\cline { 2 - 5 } \multicolumn{1}{c}{ Haylage } & Hay & *Concentrate & Haylage & Hay \\
\hline Dry matter & 704.6 & 942.7 & 948.2 & 826.4 & 945.4 \\
Organic matter & 916.7 & 923.8 & 900.3 & 908.5 & 912.0 \\
Ash & 83.3 & 76.2 & 99.7 & 91.5 & 88.0 \\
Crude protein & 142.1 & 116.6 & 112.2 & 127.1 & 114.4 \\
Neutral detergente fiber & 779.5 & 787.1 & 316.0 & 547.7 & 551.6 \\
Acid detergente fiber & 346.6 & 305.2 & 103.0 & 224.8 & 204.1 \\
Hemicelullose & 432.9 & 481.9 & 213.0 & 322.9 & 347.4 \\
Gross Energy & 4.91 & 4.58 & 4.86 & 4.89 & 4.72 \\
\hline
\end{tabular}

*70\% ground corn, $15 \%$ wheat bran, $5 \%$ soy bran, $3 \%$ calcitic lime, $2 \%$ mineral salt, $1 \%$ dicalcium phosphate, and $4 \%$ soybean oil. 
Twelve clinically healthy $10 \pm 2$-year-old Quarter Horse mares weighing $451.6 \pm 52 \mathrm{~kg}$ were used. In the week prior to the trial, the animals were treated against endoparasites and ectoparasites. Water and mineral salt were provided ad libitum throughout the experimental period of 23 days for adaptation and more five days for total feces collection.

The animals were kept in individual boxes of 9 $\mathrm{m}^{2}$ with rice straw bedding, which was completely removed during the total feces collection phase. The animals were released daily for $1 \mathrm{~h}$ in a fenced circle, where they had no access to food. On the days the feces were collected, the animals remained confined to their boxes.

The requirement of dietary nutrients was calculated according to the indications by the NRC (2007) for animals in maintenance. The animals were weighed weekly to calculate how much forage and concentrate should be provided for a 50:50 concentrate and forage ratio, corresponding to $2 \%$ of the live weight. The forage was split into three meals at $7 \mathrm{am}, 1 \mathrm{pm}$, and $5 \mathrm{pm}$, while the concentrate was provided in two meals at 9 am and $4 \mathrm{pm}$.

Feces collection started on the 24th day, when the animals were monitored for $24 \mathrm{~h}$ for the droppings to be weighed. Feces were collected in the morning directly from the rectal ampulla for sampling.

The feed and feces samples were stored in plastic bags, identified, and frozen at $-20^{\circ} \mathrm{C}$ until they were sent for the laboratory analyses that determined DM, organic matter $(\mathrm{OM})$, crude protein $(\mathrm{CP})$, digestible energy (DE), neutral detergent fiber (NDF), and acid detergent acid (ADF) contents, according to Silva and Queiroz (2002).

The trial followed a completely randomized statistical design with six replicates (mares) per treatment (haylage or hay). The data were submitted to normality and homoscedasticity analyses using Lilliefors and Bartlett's tests, respectively. Fisher's test at $5 \%$ probability was used to compare the means.

\section{Results and Discussion}

The protein fraction decreased $(\mathrm{P}<0.05)$ after 14 days of haylage production, after which it remained stable until 56 days. The opposite was observed for the ammoniacal nitrogen content, which increased $(\mathrm{P}<0.05)$ over the same period (Table 2 ).

Table 2. Chemical composition and fermentation pattern $\left(\mathrm{g} \mathrm{kg}^{-1} \mathrm{DM}\right)$ of Tifton- 85 haylage.

\begin{tabular}{|c|c|c|c|c|c|c|c|}
\hline \multirow{2}{*}{ Item } & \multicolumn{6}{|c|}{ Time after ensiled (days) } & \multirow{2}{*}{$\mathrm{CV}(\%)$} \\
\hline & 1 & 3 & 7 & 14 & 28 & 56 & \\
\hline Crude protein & $190.6 \mathrm{a}$ & $189.1 \mathrm{a}$ & $196.5 \mathrm{a}$ & $171.8 \mathrm{~b}$ & $170.9 \mathrm{~b}$ & $177.1 \mathrm{~b}$ & 4.48 \\
\hline Neutral detergente fiber & $743.1 \mathrm{a}$ & $722.3 \mathrm{a}$ & $742.6 \mathrm{a}$ & $732.1 \mathrm{a}$ & $732.4 \mathrm{a}$ & $733.3 \mathrm{a}$ & 1.42 \\
\hline Acid detergente fiber & $310.3 \mathrm{a}$ & $315.8 \mathrm{a}$ & $318.7 \mathrm{a}$ & $321.5 \mathrm{a}$ & $313.1 \mathrm{a}$ & $319.6 \mathrm{a}$ & 2.86 \\
\hline Hemicellulose & $432.7 \mathrm{a}$ & $406.4 \mathrm{a}$ & $423.8 \mathrm{a}$ & $415.6 \mathrm{a}$ & $409.3 \mathrm{a}$ & $413.7 \mathrm{a}$ & 2.89 \\
\hline $\mathrm{pH}$ & $6.08 \mathrm{a}$ & $5.19 \mathrm{a}$ & $5.53 \mathrm{a}$ & $5.37 \mathrm{a}$ & $5.42 \mathrm{a}$ & $5.21 \mathrm{a}$ & 7.41 \\
\hline Ammonia-N/total N & $0.41 \mathrm{~b}$ & $0.68 \mathrm{~b}$ & $0.74 \mathrm{~b}$ & $1.04 \mathrm{a}$ & $1.11 \mathrm{a}$ & $1.25 \mathrm{a}$ & 26.64 \\
\hline Acetic acid & $0.04 \mathrm{a}$ & $0.02 \mathrm{a}$ & $0.06 \mathrm{a}$ & $0.07 \mathrm{a}$ & $0.06 \mathrm{a}$ & $0.13 \mathrm{a}$ & 62.60 \\
\hline Propionic acid & $0.0033 \mathrm{a}$ & $0.0009 \mathrm{a}$ & $0.0036 \mathrm{a}$ & $0.0027 \mathrm{a}$ & $0.0035 \mathrm{a}$ & $0.0025 \mathrm{a}$ & 62.98 \\
\hline Butiric acid & $0.04 \mathrm{a}$ & $0.02 \mathrm{a}$ & $0.03 \mathrm{a}$ & $0.03 \mathrm{a}$ & $0.02 \mathrm{a}$ & $0.02 \mathrm{a}$ & 68.03 \\
\hline Lactic acid & $0.02 \mathrm{~b}$ & $0.17 \mathrm{~b}$ & $0.77 \mathrm{~b}$ & $0.93 \mathrm{~b}$ & $1.42 \mathrm{a}$ & $2.39 \mathrm{a}$ & 79.34 \\
\hline
\end{tabular}

Different letters in the same row differ by Scott-Knott test $(\mathrm{P}<0.05)$. 
One of the factors contributing to the low proteolysis is the conditions under which haylage was produced. Wilting prevents the enzymatic action and the activity of Clostridium, which breaks down amino acids into a series of low nutritional value compounds (McDONALD et al., 1991). According to Nishino et al. (2007), this process can also be carried out by certain strains of lactic-acid bacteria. It can be said that the process occurred slowly without compromising the ensiled grass since ammoniacal nitrogen production was low. According to Van Soest (1994), ammoniacal nitrogen contents below $10 \%$ of total nitrogen indicate that the fermentation process does not lead to excessive protein hydrolysis, which is a qualitative parameter to assess ensiled forages.

No difference $(\mathrm{P}>0.05)$ was found in the haylage's fibrous fractions (NDF, ADF and hemicellulose) over different storage periods (Table 2), which shows that the bacteria did not use these portions, particularly hemicellulose. The microorganisms used the other substrates in fermentative processes, likely soluble carbohydrates, although they appear at lower proportion compared to temperate grasses.

The presence of Lactobacillus plantarum and Pediococcus pentosaceus from the application of the additive, favors the conversion of sugar into lactic acid via glycolysis. When fermentable carbohydrates are restricted in protein-rich substrates, the microorganisms are able to decarboxylate the amino acids to generate ATP from their fermentation resulting in ammonia, short-chain fatty acids, $\mathrm{CO}_{2}$, and $\mathrm{H}_{2}$ as metabolic products. These substances can be produced by the bacteria of the genera Lactobacillus, Pediococcus, and Streptococcus (SANTOS, 1996). Besides bacteria of these genera naturally inhabiting the plant, Lactobacillus plantarum and Pediococcus pentosaceus were also introduced with the application of the biologic inoculant.

Haylage $\mathrm{pH}$ did not differ statistically (Table 2) during this experiment. Similar $\mathrm{pH}$ values were observed by Bergero et al. (2002), who found $\mathrm{pH}$ of 6.1 and 5.0 for haylage of annual ryegrass with 628.0 and $649.0 \mathrm{~g} \mathrm{DM} \mathrm{kg}^{-1}$, respectively. According to those authors, the high $\mathrm{pH}$ did not mean poorquality haylage, but rather that the high DM content limited the fermentation process.

It must be pointed out that haylage $\mathrm{pH}$ cannot be compared to that of other silages of high-moisture, because the high dry matter content in haylage limits the bacterial fermenting ability. It does not produce enough acid, and it becomes resistant against the drop in $\mathrm{pH}$. This feature must also be considered along with other factors such as the buffer capacity of forages. Thus, the standard used to evaluate haylage fermentation parameters must be different of those recommended for silage.

In the current research, the wilting down to 700 $\mathrm{g} \mathrm{DM} \mathrm{kg}{ }^{-1}$ determined the lower intensity of the fermentation process. This result matches those by McDonald et al. (1991), who stated that the variation in $\mathrm{pH}$ takes place due to the $\mathrm{DM}$ content, with a direct effect on the total count of lactic acid bacteria and the fermentation rate. Nonetheless, $\mathrm{pH}$ alone cannot be considered a parameter to assess the quality of preserved forages.

No differences $(\mathrm{P}>0.05)$ were found in the contents of acetic, propionic, or butyric acids during the time evaluated (Table 2). This haylage fermentation is likely due to low water content and the lack of or low prevalence of heterofermentative bacteria whose final metabolic products are ethanol, lactate, acetate, and $\mathrm{CO}_{2}$. These bacteria also use lactic acid and glucose as substrate to produce acetic and propionic acids (ZOPOLLATTO et al., 2009).

The butyric acid contents were close to zero $(<0.5 \%)$, which is considered desirable for ensiled forages (JONES et al., 2004). Throughout the experiment, no change $(\mathrm{P}>0.05)$ was observed in butyric acid contents, which showed the growth inhibition of Clostridium bacteria, responsible for breaking down amino acids. This result matches Jobim et al. (2007), who pointed out that the 
increase in DM content in grass silages reduces this microbial population.

With the predominance of homofermentative bacteria in the haylage from the addition of the inoculant, an increase $(\mathrm{P}<0.05)$ was observed in the lactic acid content at 28 days of silage compared to previous days. These microorganisms are characterized for producing only lactic acid as a product of their anaerobic metabolism.

According to Andrade and Melotti (2003), the more lactic acid is produced in relation to the acetic and butyric acid contents, the less energy will be expended for heat production, losses by decarboxylation, and gas formation.

In the present research, the haylage fermentation process stabilized at 28 days and no variation in fermentation pattern $(\mathrm{P}>0.05)$ was observed in the later assessments. The results obtained support the report by Müller et al. (2008) of the low contents of VFAs, lactic acid, and ammoniacal nitrogen of haylage compared to silages.

The mycotoxin contents were similar $(\mathrm{P}>0.05)$ between the plant and the haylage (56 days) and were not found at toxic levels for horses. The concentrations were $0.95 \mu \mathrm{g} \mathrm{kg}^{-1}, 0.60 \mathrm{mg} \mathrm{kg}-$ ${ }^{1}$, and $0.71 \mu \mathrm{g} \mathrm{kg}^{-1}$ for aflatoxins, fumonisin, and zearalenone, respectively. Although there is no specific concentration for the tolerance of horses to zearalenone, but the concentrations found in the present research can be considered tolerable for these animals. Raymond et al. (2003), when assessing the effects of a contaminated diet, found that the intake of $0.7 \mathrm{mg}$ zearalenone $\mathrm{kg}^{-1}$ did not cause any metabolic effect in horses.

In trial 2, no difference $(\mathrm{P}>0.05)$ was found in the DM intake (9.21 and $\left.8.06 \mathrm{~kg} \mathrm{DM} \mathrm{day}{ }^{-1}\right)$ and feces production (3.50 and 3.06 DM day ${ }^{-1}$ ) of the respective groups being fed haylage opened after 28 days of production and hay.

When the Tifton- 85 conservation methods were compared, a difference $(\mathrm{P}<0.05)$ was observed in the apparent protein digestibility, while no difference $(\mathrm{P}>0.05)$ was observed for the other fractions and energy in the diets (Table 3). However, according to the NRC (2007), the digestibility of ensiled grasses, including those preserved as haylage, is substantially higher compared with hay of the same forage.

Table 3. Apparent digestibility coefficients $\left(\mathrm{g} \mathrm{kg}^{-1} \mathrm{DM}\right)$ and digestible energy $\left(\mathrm{Mcal} \mathrm{kg}^{-1}\right)$ of the experimental diets.

\begin{tabular}{lccc}
\hline \multirow{2}{*}{ Digestibility coefficients } & \multicolumn{2}{c}{ Diet (concentrate + forage type) } & \multirow{2}{*}{ CV (\%) } \\
\cline { 2 - 3 } & Haylage & Hay & 8.73 \\
Dry matter & $618.1 \mathrm{a}$ & $615.9 \mathrm{a}$ & 8.05 \\
Organic matter & $650.5 \mathrm{a}$ & $631.9 \mathrm{a}$ & 11.49 \\
Crude protein & $675.1 \mathrm{a}$ & $579.1 \mathrm{~b}$ & 12.28 \\
Neutral detergente fiber & $590.0 \mathrm{a}$ & $596.6 \mathrm{a}$ & 20.19 \\
Acid detergente fiber & $544.4 \mathrm{a}$ & $517.7 \mathrm{a}$ & 9.37 \\
Hemicelluloses & $621.8 \mathrm{a}$ & $640.8 \mathrm{a}$ & 9.58 \\
Digestible energy & $63.84 \mathrm{a}$ & $60.01 \mathrm{a}$ & \\
\hline
\end{tabular}

Different letters in the same row differ by Fisher's test $(\mathrm{P}<0.05)$.

Moore-Colyer and Longland (2000) compared the impact of the forage conservation method on nutrient digestibility of hay $\left(922.0 \mathrm{~g} \mathrm{DM} \mathrm{kg}^{-1}\right)$ and haylage $\left(676.0 \mathrm{~g} \mathrm{DM} \mathrm{kg}^{-1}\right)$ in ponies. Those authors found digestibility coefficients higher $(\mathrm{P}<0.05)$ for DM, OM, CP and GE of 570.0, 573.0, 484.0, and 
$519.0 \mathrm{~g} \mathrm{~kg}^{-1} \mathrm{DM}$ for animals fed with haylage while hay yielded values of 389.0, 400.0, 198.0, and 331.0 $\mathrm{g} \mathrm{kg}^{-1} \mathrm{DM}$ for the same variables.

The present research found an increase in apparent protein digestibility in the group of animals that received haylage as forage, which may be because, when well produced, haylage represents a nutritional advantage to horses for its greater availability of amino acids absorbed in the small intestine before reaching the caecum-colon (MUHONEN et al., 2009). It is worth pointing out that a biological inoculant was added in haylage production, which may have contributed to the higher digestibility of the diet's protein fraction.

\section{Conclusions}

Tifton- 85 haylage can be used in horse diets starting at 28 days of storage. Horses fed diets with Tifton-85 haylage have higher apparent protein digestibility. Therefore, haylage represents an alternative to preserve forage for horse feed.

\section{References}

ANDRADE, S. J. T.; MELOTTI, L. Inoculantes bacterianos na silagem do capim elefante (Pennisetum purpureum, Schum). Brazilian Journal of Veterinary Research and Animal Science, São Paulo, v. 40, n. 3, p. 219-223, 2003.

BERGERO, D.; PEIRITTI, P. G.; COLA, E. Intake and apparent digestibility of perennial haylages fed to ponies either at maintenance or at work. Livestock Production Science, Amsterdam, v. 77, n. 2, p. 325-329, 2002.

JOBIM, C. C.; NUSSIO, L. G.; REIS, R. A.; SCHMIDT, P. Avanços metodológicos na avaliação da qualidade da forragem conservada. Revista Brasileira de Zootecnia, Viçosa, MG, v. 36, p. 101-119, 2007.

JONES, C. M.; HEINRICHS, A. J.; ROTH, G. W.; ISHLER, V. A. From harvest to feed: understanding silage management. Pennsylvania: Pennsylvania State University, 2004. 37 p.

KUNG JÚNIOR, L.; STOUGH, E. C.; MCDONELL, E. E.; HOFHERR, M. W.; REICH, L. J.; KLINGERMAN, C. M. The effect of wide swathing on wilting times and nutritive value of alfafa haylage. Journal Dairy Science, Champaign, v. 93, n. 4, p. 1770-1773, 2010.

McDONALD, P.; HENDERSON, A. R.; HERON, S. J. E. Biochemistry of silage. $2^{\text {th }}$ ed. Marlow: Chalcombe Publication, $1991.340 \mathrm{p}$.

MOORE-COLYER, M. J. S.; LONGLAND, A. C. Intakes and in vivo apparent digestibility of four types of conserved grass forage by ponies. Journal of Animal Science, Champaign, v. 71, n. 3, p. 527-534, 2000.

MUHONEN, S.; JULLIAND, V.; LINDBERG, J. E.; BERTILSSON, J.; JANSON, A. Effects on the equine colon ecosystem of grass silage and haylage diets after an abrupt change from hay. Journal of Animal Science, Champaign, v. 87, n. 7, p. 2291-2298, 2009.

MÜLLER, C. Long-stemmed vs. cut haylage in bales effects on fermentation, aerobic storage stability, equine eating behaviour and characteristics of equine faeces. Animal Feed Science and Technology, Amsterdam, v. 152, n. 3-4, p. 307-321, 2009.

MÜLLER, C. E.; UDÉN, P. Preference of horses for grass conserved as hay, haylage or silage. Animal Feed Science and Technology, Amsterdam, v. 132, n. 1-2, p. 66-78, 2007.

MÜLLER, C. E.; VON ROSEN, D.; UDÉN, P. Effect of forage conservation method on microbial flora and fermentation pattern in forage and in equine colon and faeces. Livestock Science, Amsterdam, v. 119, n. 1-3, p. 116-128, 2008.

NATIONAL RESEAR0043H COUNCIL - NRC. Nutrient requirements of horses. $6^{\text {th }}$ ed. Washington: National Academy Press, 2007. 341 p.

NISHINO, N.; HATTORI, H.; WADA, H.; TOUNO, E. Biogenic amine production in grass, maize and total mixed ration silages inoculated with Lactobacillus casei or Lactobacillus buchneri. Journal of Applied Microbiology, Oxford, v. 103, n. 2, p. 325-332, 2007.

PASTORINI, L. H.; BACARIN, M. A.; ABREU, C. M. Secagem de material vegetal em forno de micro-ondas para determinação de matéria seca e análises químicas. Ciência e Agrotecnologia, Lavras, v. 26, n. 6, p. 12521258, 2002.

RAGNARSSON，S.; LINDBERG，J. E. Nutritional value of timothy haylage in Icelandic horses. Livestock Science, Amsterdam, v. 113, n. 2, p. 202-208, 2008.

RAYMOND, S. L.; SMITH, T. K.; SWAMY, H. V. L. N. Effects of feeding a blend of grains naturally contamined with Fusarium mycotoxins on feed intake, serum chemistry, and hematology of horses, and the efficacy of a polymeric glucomannan mycotoxin adsorbent. Journal 
of Animal Science, Champaign, v. 81, n. 9, p. 2123-2130, 2003.

SANTOS, M. H. S. Biogenic amines: their importance in foods. International Journal of Food Microbiology, Amsterdam, v. 29, n. 2-3, p. 213-231, 1996.

SILVA, D. J.; QUEIROZ, A. C. Análises de alimentos: métodos químicos e biológicos. Viçosa, MG: Imprensa Universitária, 2002. 235 p.
VAN SOEST, P. J. Nutritional ecology of the ruminant. $2^{\text {th }}$ ed. New York: Cornell University Press, 1994. 476 p.

ZOPOLLATTO, M.; DANIEL, J. L. P.; NUSSIO, L. G. Aditivos microbiológicos em silagens no Brasil: revisão dos aspectos da ensilagem e do desempenho dos animais. Revista Brasileira de Zootecnia, Viçosa, MG, v. 38, p. 170-189, 2009. Número Especial. 